DOI https://doi.org/10.30525/978-9934-26-075-9-18

\title{
FEASIBILITY OF ULTRASOUND EXAMINATION IN THE DIAGNOSIS OF LOCAL SPREAD OF THYMUS TUMORS
}

\author{
Minuhin D. V.
}

Candidate of Medical Sciences, Associated Professor, Associated Professor at the Department of Surgery No. 1

Kharkiv National Medical University

Yatsenko Ye. S.

Radiologist (specialized in ultrasonography)

State Institution Zaycev V. T.

Institute of general and urgent surgery

of National Academy of medical sciences of Ukraine

\section{Yevtushenko D. O.}

Doctor of Medical Sciences, Professor, Professor at the Department of Surgery No. 1

Kharkiv National Medical University

\section{Kudrevych I. O.}

Candidate of Medical Sciences (PhD),

Associated Professor at the Department of Endoscopy and Surgery

Kharkiv Medical Academy of Postgraduate Education

\section{Kritsak V. V.}

Surgeon at the Department of Thoraco-Abdominal Surgery

State Institution Zaycev V. T.

Institute of general and urgent surgery

of National Academy of medical sciences of Ukraine

Kharkiv, Ukraine

Thymus tumors in the structure of cancer occupy 3-6\%, up to $60 \%$ of them are malignant $[1,3,5]$. Errors in tumors of the thymus diagnosis can reach $25-60 \%[1,2]$. Only timely and accurate diagnosis of tumor lesions can improve treatment outcomes and prognosis for life in these patients. In relation with the development of thoracic oncosurgery, the feasibility of surgical 
treatment of thymic tumors even further increases the value of data about true distribution of the tumor process $[3,4]$.

Radiation methods play a leading role in the diagnosis of tumors of the mediastinal organs, the main of which is spiral computed tomography (SCT) $[1,4,5]$. Clarification of the local distribution of the tumor process at the preoperative stage allows to choose an adequate type of treatment in these patients (surgical, chemoradiation, combined), and when choosing a surgical treatment - to plan the volume of an operation. However, the number of errors in determining the prevalence of tumors of the mediastinal organs is still quite high $[1,3]$. The value of non- roentgenological methods for the mediastinal organs examination, such as ultrasound (US), has not been sufficiently studied $[1,2,3]$.

Objective of the study: to evaluate the clinical efficacy of the ultrasound method of the chest organs examination in patients with thymomas in the evaluation of the local spread of the tumor process to the surrounding anatomical structures.

Meterials and methods. The study included 132 patients with thymus tumors, who had undergone a surgical operation in the Department of Thoraco-Abdominal Surgery of the State Institution "VT Zaitsev Institute of General and Emergency Surgery, National Academy of Medical Sciences of Ukraine" which is the clinical base of the Department of Surgery No. 1 of Kharkiv National Medical University.

Ultrasound examination for thymic tumors was performed using probes operating in real time in a gray scale mode on an equipment Aplio 400 («Toshibo», Japan). Convex and linear electronic scanning probes with a frequency of $3 ; 3.5 ; 4 ; 5$ and $7 \mathrm{MHz}$, operating in real time, as well as probes with a variable frequency of $2.5-5 ; 3.67-8.0$ and $5.0-10.0 \mathrm{MHz}$ were used.

Ultrasound examination was performed first in the supine position with the head thrown back and then in sitting position. During ultrasound examination, several approaches were used: transsternal, parasternal, through the intercostal spaces, suprasternal and through the inferior aperture of the chest, scanning was performed in two planes (longitudinal and transverse) and additionally in oblique longitudinal and oblique transverse scanning planes, multi-positionally to obtain the most optimal images.

Depending on the nature of the relative position of the tumor with the surrounding tissues, the following variants of the obtained ultrasound picture can be distinguished: 1) no relation - there is no involvement in the tumor process; 2) growth or adhesion process - there can be involvement in the tumor process; 3 ) ingrowth, distribution - there is involvement in the tumor process. 
The following ultrasound signs of invasion into adjacent anatomical structures were revealed: a) immobility of the tumor relative to the chest wall during breathing; b) tumor infiltration of the soft tissues of the chest wall; c) destruction of bones (more often ribs, less often the marginal part of the sternum) and their replacement with tumor tissue.

The presence of any of the described signs was the basis for the conclusion about the involvement of adjacent tissues in the tumor process. The discovery of the second and / or third sign made it possible to describe the nature of growth more detailly (depth, length, degree of involvement).

Results and their discussion. Each of 132 patients underwent a planned surgical operation. Various options for thymectomy were performed. The pathomorphological examination of the operating material revealed the following structure of the tumor affections of the thymus: in 109 (84.1\%) patients - epithelial tumors of the thymus; in $14(10.6 \%)$ patients mesenchymal tumors of the thymus (thymolipomas); 7 (5.3\%) patients had dysembryonic tumors (teratomas).

When using ultrasound in determining the local spread of the tumor process in patients with thymomas and comparing them with intraoperative data, the following results were obtained: true-positive (TP) -22 , true-negative (TN) - 107, false-positive (FP) - 2, false-negative (FN) - 1 .

Based on the data presented, the effectiveness of the ultrasound method in diagnosing the local spread of the tumor process in this pathology was calculated: the sensitivity was $95.7 \%$, specificity $-98.2 \%$, and the overall accuracy $-97.7 \%$.

In the SCT scan, the following results were obtained: TP -20 cases, TN 106 cases, FP -3 cases, FN -3 cases. When assessing the effectiveness of the method, the sensitivity was $86.0 \%$, specificity $-97.2 \%$, and the overall accuracy $-95.5 \%$.

The data obtained clearly demonstrate that in patients with thymomas, ultrasound is a more effective method for diagnosing the local spread of the tumor process $(\mathrm{p}<0.01$, the difference is statistically significant). The higher efficiency of ultrasound in determining the relationship of the tumor with the surrounding structures is explained by conducting a study in real time, which allows the use of functional signs in diagnosis.

Conclusions. In patients with thymomas, ultrasound is an effective method for detecting the local spread of the tumor process to the surrounding anatomical structures, it allows to determine the depth, extent and degree of invasion. Comparison of the capabilities of the ultrasound and SCT method showed that ultrasound is statistically significantly superior to SCT in sensitivity, which is very important when planning surgical treatment and its volume. 


\section{References:}

1. Александров О.А., Степанов С.О., Пикин О.В., Волченко Н.Н., Соловьев В.А., Беспалов П.Д., Вурсол Д.А. Трансторакальная толстоигольная биопсия опухолей средостения под контролем ультразвуковой навигации. Онкология. Журнал им. П.А. Герцена. 2019. № 8(2). С. 88-93. doi: /10.17116/onkolog2019802188

2. Казакевич В.И. Возможности ультразвукового исследования в диагностике прорастания опухолей легкого и средостения в грудную стенку. Онкология. Журнал им. П.А. Герцена. 2014. № 3(2). С. 8-13.

3. Майорова М.В., Казакевич В.И., Волченко Н.Н., Степанов С.О., Мыслевцев И.В., Тюрина Н.Г., Вернюк М.А., Червонцева А.М. Роль мультифокальной трепанобиопсии под контролем УЗИ в комплексной диагностике лимфомы. Онкология. Журнал им. П.А.Герцена. 2017. № 6(1). C. 19-22. doi /10.17116/onkolog20176119-22

4. Панфёрова Т.Р., Никулина А.Л., Серебрякова И.Н., Поляков В.Г. Ультразвуковая диагностика эктопированной ткани тимуса в щитовидной железе у детей. Онкопедиатрия. 2015. №2(2). С. 109-114. doi: 10.15690/onco.v2i2.1341

5. Hakiri S., Kawaguchi_K., Fukui T., Nakamura S., Ozeki N., Mori S., et al. Verification of the diagnostic strategy for anterior mediastinal tumors. Int J Clin Oncol._2019 Apr. 24(4). P. 385-93. doi: 10.1007/s10147-018$1362-8$. 